\title{
Narratives of ethnic identity and language among young Pannonian Ruthenians in Serbia
}

"[...] there is not, there has never been anywhere, any people without narrative; all classes, all human groups, have their stories [...]"

Roland Barthes

\section{Introduction}

T his article offers a study of personal experiences and understandings of Ruthenian ethnic minority identity in Serbia. The narrative approach was selected as the most appropriate method to gain insight into its intersubjective perception. The narratives under consideration are viewed as personal story-telling and are presented in the context of the political and social discourse of ethnic identities and minorities in particular. The bilingual upbringing of all Ruthenians in Serbia poses as one of the key factors behind a political position which enabled them to avoid assimilation with the majority. This study can be taken as an example of how minorities (ethnic, linguistic or otherwise) can obtain their rights within nation-states through strategic positioning aiming to withstand the cultural and linguistic hegemony of the majority.

The migration of Ruthenians form the region of Transcarpathia in the north-east of the historical Kingdom of Hungary (Kraljevina Ugarska) to the south of the realm, today's Vojvodina (Srem, Banat, Bačka), Serbia, began in the mid-eighteenth century 
(Ramač, 1995, p. 307). In the areas of their settlement, they consolidated as an ethnic group with its own traditions, religion, heritage, language and culture. They also adopted strategies aiming to obtain minority rights: they established their educational, cultural, political and publishing institutions. Their official recognition as a national minority meant that the Ruthenian language (Ruski jazik) became one of the six official languages in the Autonomous Province of Vojvodina, used in administrative, judicial and other public settings.

Providing a historical overview of the most important elements of Ruthenian cultural and linguistic background since the settlement in Vojvodina until the present day will make it easier to understand the attitude of my interviewees towards their own cultural identity. The information presented here is considered an "official" history of Vojvodinian Ruthenians: it is taught in the curriculum in the Ruthenian high school as well as in the elective Ruthenian cultural classes. Calling this history "official" is not meant to question it or to imply that it is not factual - I merely refer to the fact that my interests and expertise as well as my academic background lie in a different field of study: ethnology and anthropology. I am therefore more interested in understanding how these identities are imagined, re-imagined, strategically positioned and whether my informants have agency over their own ethnic identity. My goal is not to determine whether or not the historical information is true or false, but to understand how certain identities are interconnected and related to one another.

The data analysed in this article was collected through in-depth semi-structured interviews and questionnaires conducted in Ruthenian with nine informants in Novi Sad, Serbia, in 2016, as well as four preliminary interviews. The informants selected for this study were Ruthenians (born between 1991 and 1997) from Ruski Krstur and Novi Sad studying at the University of Novi Sad who consider themselves Ruthenian. In order to perserve their anonimity, the citations only include information on their gender and the year they were born.

I have strived to be unbiased and impartial to the best of my ability, considering that I am a member of the Ruthenian community, and that both of my parents are currently employed in Ruthenian institutions. Any misinterpretations, misrepresentations and mistranslations that this article may contain are entirely mine.

\footnotetext{
${ }^{1}$ Hereafter abbreviated as AP Vojvodina.
} 


\section{Terminology}

There have been many ethnonyms used to define Ruthenians, some of them raising questions of certain political agendas during the process of struggle for minority rights and securing the status of a national minority in the Kingdom of Serbs, Croats and Slovenes (1918-1929). Connected to the linguistic and ethnic origins, these issues have been present for centuries, as the etymology is complex and multifaceted. The term Ruthenian was used to describe a cultural and linguistic identity of East Slavic people living in the region of Ruthenia, which was part of Kievan Rus, Polish-Lithuanian Commonwealth, the Kingdom of Hungary, the Austro-Hungarian empire and their successor states after 1918 (Magosci, 1995). An important dividing line between Ruthenians and other ethnicities in Vojvodina has been religion: they are viewed as a Greek-Catholic community in Serbia. Fedor Labosh wrote that "[...] if they [our grandfathers, M. S.] had been Orthodox, they would not have been able to sign up for resettlement"; in other words, they would not have been eligible for migration to Vojvodina (Labosh, 1979, p. 184).

The term I believe best explains the ethnic identity of my informants, and which I use here, is Pannonian Ruthenian (Rusyn), ${ }^{2}$ encompassing today's Ruthenians living in Serbia, Croatia, Hungary, Slovakia, Poland, Ukraine and Romania. The ethnonym for Pannonian Ruthenian in the Kingdom of Yugoslavia ${ }^{3}$ was Rusyn (Rusin). Based on a study by Zdravka Zlodi and the data she collected, we know that a number of other ethnonyms had been used for Ruthenians in the Croat part of the Kingdom of Yugoslavia between 1924 and 1941 (and presumably earlier) - Rusin, Rusnak, Rusin-Ukrajinac, Ukrajinac, ruski narod (Zlodi, 2011, p. 221).

\section{An official history of Ruthenians}

A brief overview of the chronology of the Ruthenian migration to Vojvodina is important in order to understand the reality of the period as well as the historical, political, religious and cultural background of this community and their perception of their own ethnic identity. The migration of Ruthenians from Transcarpathia (Zakarpatje, Western Ukraine, Poland, Slovakia) to the south of the Kingdom of Hungary within the Habsburg Monarchy,

\footnotetext{
${ }^{2}$ The term Rusyn (Rusin/Rusinka, Rusnak/Ruskinja) corresponds to what the people call themselves in Serbia.

${ }^{3}$ The South Slavic state which existed from 1918 to 1941 under two names: the Kingdom of Serbs, Croats and Slovenes (1918-1929), and the Kingdom of Yugoslavia (1929-1941).
} 
present-day Vojvodina, Serbia, began during the eighteenth century and was motivated by economic and political factors (Labosh, 1979, pp. 54-84). Issued on 17 January 1751, the decree on Ruthenian settlement in the south officially allowed Ruthenians to migrate to small towns such as Ruski Krstur and Kucura, where some of them had already arrived in 1745 (Labosh, 1979, pp.64-65). Today, this date is celebrated as the official national holiday of all Ruthenians in Serbia.

They are Greek-Catholic, and their self-image of a unique union between Catholicism and Orthodoxy is considered important in the collective imagery of Ruthenian identity. Catholic influence on the generally Orthodox region of Ruthenia goes back to the Union of Brest (1596): the acceptance of the supremacy of the Pope was supposed to be the first step of Catholicization of Ruthenians (Litwin, 1987, pp. 69-71). Apart from this, processes which were part of the modernization of the Roman Catholic Church in the seventeenth century led to the Union of Uzhhorod/Ungvár (1646). The unification of Eastern-rite Christians with Rome and the acceptance of the teaching of the Roman Catholic Church were primarily motivated by the local church, Hungarian society and Hungarian ecclesiastical policy (Véghseő, 2015, pp. 148-152). The Hungarian historian Tamás Véghseő writes that "Archbishop of Esztergom György Lippay, in informing the Holy See about the union, [...] [states] that he has 'converted the Patriarch of the Ruthenians'" (Véghseö, 2015, p. 149).

The Greek-Catholic denomination is often considered one of the most important distinctions between the ancestors of modern Ruthenians, Poles, Ukrainians and Slovaks, who all have similar descent in the region of Ruthenia, especially when we consider the time period - the late sixteenth and early seventeenth centuries. This line of division is also important when talking about the Ruthenian identity in Vojvodina, because it differentiates Ruthenians from other communities in the region. Julijan Tamaš, a Ruthenian academic at the Vojvodina Academy of Sciences and Arts, observes: "Based on that denomination, Ruthenians in the Carpathian region were distinct from Orthodox Ukrainians (there were also Ukrainians who were Uniates) and from Evangelical Slovaks, and in Vojvodina - from Orthodox Serbs and Romanians, Catholic Hungarians, and Evangelical Slovaks who settled in Vojvodina at the same time" (Tamaš, 1984, p. 39). ${ }^{5}$

\footnotetext{
${ }^{4}$ The Union of Brest extenden to the Polish-Lithuanian Commonwealth, present-day Central and East European countries: Poland, Ukraine, Belarus, Russia, Lithuania and others.

${ }^{5}$ The original quotation in Serbian: "Po toj veri Rusini su se razlikovali u karpatskom basenu i od pravoslavnih Ukrajinaca (bilo je Ukrajinaca i unijata) i od evangelističkih Slovaka, a u Vojvodini od pravoslavnih Srba i Rumuna, katoličkih Mađara i evangelističkih Slovaka naseljenih u istim seobama u Vojvodinu" (Tamaš, 1984, p. 39).
} 
It is worth mentioning that Ruthenians built their Greek-Catholic church in Ruski Krstur in 1753, only two years after the official decree on their settlement (Labosh, 1979, pp. 243-278). This is important in order to understand how these historical facts have shaped and affected the conceptualization of their religious identity as different, special and even superior to a certain degree.

Apart from their church, they also established schools in Ruski Krstur (1753) and in Kucura (1756). Although they were confessional schools, under the patronage of the church, they were funded by local residents, who thus had agency over the appointment of teachers (Tamaš, 1984, pp.43-44). The curriculum was taught in Ruthenian and included religious instruction as well as literacy and numeracy. When the school in Ruski Krstur became communal in 1888, the official language of instruction was changed to Hungarian, which was interpreted as an attempt to assimilate local Ruthenians with the Hungarian people. From 1918 - when it became a state school under the Kingdom of Serbs, Croats and Slovenes, and later on, its successor, the Kingdom of Yugoslavia - the classes were taught in Ruthenian again (Tamaš, 1984, pp.43-44).

One of the teachers in Ruski Krstur was Petro Kuzmjak (1816-1900), who taught there from 1850 until 1887 and is known as the first Ruthenian poet in the region (Tamaš, 1984, p. 44); the school bears his name today. ${ }^{6}$ Another local teacher, Mihail Vrabelj (1866-1923), made a record of oral poetry and published it as the first literary work in Ruthenian - "Ruthenian Nightingale" (Rusinski slavuj, 1890) is considered the beginning of Ruthenian literature. He was also the author of a spelling-book and an editor of the Budapest-based weekly Nedelja (Sunday) (Tamaš, 1984, pp.44-48). The work of these teachers and their successors shows the importance attached by the Ruthenian community to education and the preservation of their language and heritage.

The Ruthenian National Education Society (Ruske narodno prosvitne družtvo, RNPD), established in Novi Sad in 1919 by the priest Đura Bindas (Tamaš, 1997, p. 70), became an institution which laid the foundations for a strategy to acquire minority rights for the Ruthenian community in the Kingdom of Serbs, Croats and Slovenes. Havrijil Kosteljnik Gomzov (1886-1948), in turn, is viewed as the founding father of Ruthenian literature and the figure behind the official status of the Ruthenian language in today's Vojvodina. Apart from writing one of the most valuable literary works in Ruthenian - "The Idyllic Wreath: From my Village" (Idilski veniec. Z moloho valala, 1903) (Tamaš, 1984, pp. 87-110) - he also authored "A grammar of

\footnotetext{
${ }^{6}$ This is the only elementary and high school in Serbia with Ruthenian as the language of instruction; more information can be found at its official website: https://petrokuzmjak.com/
} 
the Ruthenian Speech of Bačka"' (Gramatika bachvan'sko-rusker beshedi, 1923), the first grammar of the western Ruthenian language, which provided the basis for the official standardization of one of the youngest Slavic languages at the time (Tamaš, 2008, p. 17). This paved the way for publishing in Ruthenian; the publishing house called Ruske slovo (Ruthenian word) ${ }^{8}$ was founded in 1945 in Ruski Krstur and moved to Novi Sad in 1968; it is one of the most important centres of dissemination of political, social, educational, economic and religious thought.

As it is today, the 2006 constitution of the Republic of Serbia guarantees the rights of minorities. Article 14 provides: "The Republic of Serbia shall protect the rights of national minorities. The State shall guarantee special protection to national minorities for the purpose of exercising full equality and preserving their identity" (The Constitution of the Republic of Serbia, 2006). ${ }^{9}$

In other words, they are not only allowed to cultivate their identity, heritage and speak their language, but also to establish their own institutions, whether cultural, educational, religious or political. Ruthenians have been obtaining their rights since their migration to present-day territory of AP Vojvodina. In political and cultural terms they have clearly distinguished themselves from Ukrainians, an important factor for the standardization of their language - historically considered a dialect of Ukrainian, ${ }^{10}$ it has become one of six official minority languages in AP Vojvodina.

The standardization of their language enabled Ruthenians not only to issue print media, but also to produce radio and TV broadcasts in Ruthenian. In 1972 they established the Department of Ruthenian Studies (Katedra za Rusinistiku) - a discipline that studies the language, literature, culture and history of Ruthenians - at the University of Novi Sad, offering courses at all leves of academic education (BA, MA and PhD).

The awarness of extensive minority rights that have existed but have also been fought for over decades enables minorities in AP Vojvodina to cultivate their heritage and their ethnic identity if they wish to do so.

\footnotetext{
${ }^{7}$ Bačka is one of three larger regions in AP Vojvodina where Ruthenians migrated in the eighteenth century.

${ }^{8}$ Ruske slovo publishes the weekly Ruske slovo (Ruthenian word); Mak (The Poppy), a monthly multimedia magazine for young people; Zahradka (The Garden), a monthly magazine for children; Shvetlosts (Light), an academic, literary, cultural and arts journal; the annual Ruski hristiianski kalendar (Ruthenian Christian Calendar); it also publishes books and runs an online news agency Rutenpress. More information is available at the official website of the publishing house Ruske slovo at http://www.ruskeslovo.com/

${ }^{9}$ More information can be found in the Constitution of the Republic of Serbia available at http://www.parlament.gov.rs /upload/documents/Constitution_\%20of_Serbia_F.pdf (The Constitution of the Republic of Serbia, 2006).

${ }^{10}$ More information about the Ruthenian-Ukrainian relations in Serbia can be found on the official website of the Union of Ruthenians and Ukrainians of Serbia (formerly of Yugoslavia): http://www.rusuk.org/ruski/organizacija/index.htm (accessed 11 November 2019).
} 


\section{Narratives - storytelling}

Studying and trying to better understand the complexities and personal experiences of my informants in this article, I heavily draw on the conceptual frameworks that deal with narrative, discourse, essentialism, agency and ethnic boundaries. The modus operandi that I have found most helpful in this kind of study is the narrative approach. The literary theorist, philosopher, critic and semiotician Roland Barthes, obsereved as follows:

Among the vehicles of narrative are articulated language, whether oral or written, pictures, still or moving, gestures and an ordered mixture of all those substances; narrative is present in myth, legend, fables, tales, short stories, epics, history, tragedy, drame [suspense drama], comedy, pantomime, paintings [...], stained-glass windows, movies, local news, conversation (Barthes, 1975, p. 237; stress added by M. S.).

This quote explains the narrative approach as something more than just an analysis of literary texts, because we can see how people tend to construct a coherent, logical and linear story of their lives while being interviewed - and this is what is called story-telling. I consider this approach useful in understanding the depths and complexities of an ethnic identity of my informants, which I will try to describe to the best of my ability.

Paraphrasing Hannah Arendt, Michael Jackson has explained how "storytelling is never simply a matter of creating either personal or social meanings, but an aspect of the 'subjective in-between' in which a multiplicity of private and public interests are always problematically in play" (Jackson, 2002, p. 11). He takes into account larger discourses that are either internalized or fought against by individuals who want to have agency over their identities. An important point to make here is that individuals might be convinced that a certain understanding of their identity is "normal" or "natural" without knowing how or when or why it was constructed in such a way; one of the reasons could be political instrumentalization. This is not to say that I consider that my informants are misinformed or misled. I only consider it as a possibility that the reasons for certain essentialist ${ }^{11}$ outlooks come from certain positions of power, which individuals are often unaware of (if this is the case, it means that political instrumentalization has been effective).

11 "[...] cultural essentialism, the idea that cultural group membership can be defined in terms of a specific set of necessary and sufficient conditions" (Young 2005). 
That being said, it is also important to define the term 'ethnicity' - the definition that I use in this article is one proposed by the Norwegian social anthropologist Thomas Hylland Eriksen, who views it as "the systematic and sustained reproduction of basic classificatory differences between groups, whose members thereby define themselves as being culturally distinctive from the members of other groups, which are defined in a similar way" (Eriksen, 1992, p. 314). Apart from this, Eriksen also points out the rules of marital endogamy that are often practised in minority groups. The topic has been brought up in the interviews with my informants, but endogamy rules are more of an ideal to aspire to than fixed rules of conduct.

Based on the information from in-depth interviews and questionnaires, I have noticed variations in the informants' conceptualization of ethnic identity. Their replies differed depending on their age and place of birth: whether they were born in the small town of Ruski Krstur (with a population of 4,585, according to the 2011 census) or the city of Novi Sad (with a population of 341,625) ("Statistical Office of the Republic of Serbia, Census 2011, Comparative overview of the number of population in 1948, 1953, 1961, 1971, 1981, 1991, 2002, 2011", n.d.). It has become apparent in the study that it is important to make a distinction between the informants based on the area where they grew up (rural vs. urban upbringing). In fact, they noticed differences in the socialization and general conduct themselves: they mentioned how growing up in the city made Ruthenians more open and assertive, and more inclined to listen to Serbian "turbo folk" music. This music genre is considered to be of low quality and poor taste, and bears certain class connotations; apart from that, it is also viewed as an ethnic marker. ${ }^{12}$

While talking to my interviewees about their personal experiences as members of an ethnic minority, I observed two main modes of conveying their understanding of their own ethnic identity. Presenting these modes in this article, I apply the narrative analysis approach (Barthes, 1975) in order to identify the narratives through which they are able to express the depth of how they conceive their ethnic identity and language. As these narratives are interconnected in a way that makes it impossible to divide the two distinct modes, I will present them in conjunction.

There are two different outlooks apperent in how the informants expressed their understanding of their ethnic identity. One is more "traditional", in essentialist terms, whereby

\footnotetext{
${ }^{12}$ More information about this is available in the article by Marina Simić entitled "Exit into Europe: Popular music and identity politics in contemporary Serbia" (Exit u Evropu: Popularna muzika i politike identiteta u savremenoj Srbiji). As used here, the word 'exit' has two meanings: one is the name of a music festival in Novi Sad, which played an important role in the political agency of young people from Novi Sad after the rule of Slobodan Milošević; the other meaning refers to migration to EU countries after 2000 (Simić, 2006).
} 
being Ruthenian means being born as a Ruthenian into a Ruthenian family, not necessarily viewed as a biological trait, but definitely defined by being brought up by Ruthenian parents. The other one, more "modern" understanding is that one has agency over their own identity: a female informant considers herself "a cosmopolitan", a citizen of the world, but also acknowledges the fact that apart from her Ruthenian heritage and upbringing, she does have certain Serbian traits as well:

I feel like a cosmopolitan; I'm not only a Ruthenian or a Serb, I'm a citizen of the world (female, born in Novi Sad, 1996). ${ }^{13}$

As mentioned above, these two elements (ethnic and linguistic) are intertwined into a complex component of the modes in which my informants convey their interpretation of their ethnic identity. The opportunity to learn, speak and publish in one's mother tongue should be viewed as a social and political use of language. They take pride in speaking their mother tongue and being able to use it without being discriminated against.

The definition of cultural essentialism proposed by the social anthropologist Ralph Grillo is useful in understanding the attitudes that my interviewees have towards their ethnic identity. What he means by cultural essentialism is "a system of belief grounded in a conception of human beings as 'cultural' (and under certain conditions territorial and national) subjects, i.e. bearers of a culture, located within a boundaried world, which defines them and differentiates them from others" (Grillo, 2003, p. 158). When asked to explain what it means to be or feel like a Ruthenian, one of my interviewees stated as follows:

Because I speak Ruthenian, because my parents are Ruthenian, because I know about the history, I think mostly because it is important to me, it's not something that has no significance, it is who I am, I have been like this my whole life, and I think I just don't think about it (female, born in Novi Sad, 1996). ${ }^{14}$

One important aspect of this essentialist conceptualization is defining "true" Ruthenias and ones that are not:

\footnotetext{
${ }^{13}$ Transliteration of the original quote: "Chuvstvuiem she iak kosmopolita, ia nie liem Ruskinia abo Serbkinia, ia hrazhdan shveta" (female, born in Novi Sad, 1996).

${ }^{14}$ Transliteration of the original quote: "Zato zhe besheduiem po ruski, zato zhe mi rodichi Rusnatsi, zato zhe znam o istoriï, dumam ustvari zhe naĭbarzheĭ zato zhe mnie to bitne, i to nie tsoshka tso z boku, to iednostavno ia, ia taka tsali zhivot i dumam, nie rozdumuiem o tim iednostavno" (female, born in Novi Sad, 1996).
} 
It's based on a social foundation, because society has an impact on you; for example, when you're in a larger environment, I don't know, Novi Sad or Belgrade, here and there, you act like the community, some norms are different than in the village; and I've noticed that, for example, Ruthenians in Novi Sad have Serbian norms, simply, I don't know. They listen to Serbian folk music, or they go out where there is Serbian folk music and stuff like that; I don't know exactly, but you know, when I'm in Kerestur, for example, I would never go to such a place (male, born in Ruski Kerestur, 1991). ${ }^{15}$

Interestingly, although essentializing one's own culture is evident here, in terms of imagining "real", unaffected ethnicity there is an understanding of social norms and values that can affect one's identity. These kinds of contradictions are what helps us to understand the depths and complexities in which people position themselves in terms of their identities. This does not mean that their convictions and ideas are wrong, or that they should eliminate their ethnic identity - it only shows that these kinds of identities are in fact something that an individual can have agency over and does not have to necessarily adhere to in a traditional sense. For example, this interviewee naturalizes certain conduct as part of ethnic identity:

Those Serbs that I went to high school with were quite loud, they didn't really have respect for the teachers, they behaved more freely in comparison to our Ruthenian class [...]; of course we in the Ruthenian class were calmer and more restrained, we didn't shout during the lessons, but it was also hard to get answers out of us. We were afraid that we would say something wrong, so we didn't talk. When it comes to this, Serbs behave more freely, this is something that we lack (female, born in Ruski Kerestur, 1994). ${ }^{16}$

We can notice how this interviewee implies that people are "naturally" born with the skill to be more assertive, but also compares the two ethnicities as if there were a set of behaviours and values typical of all Serbs or all Ruthenians as homogenous groups.

${ }^{15}$ Transliteration of the original quote: "To na sotsiialnei bazi, preto zhe vono druzhtvo uplïvuie na tse, na primer ked ti u vekshim okruzheniu, nie znam, Novi Sad, Beograd, lïvo, pravo, ti she spravuiesh iak druzhtvo, datso, daiedni normi inshaki iagod ked shi u valalu i vetska som vidzel zhe na primer, Rusnatsi u Novim Sadze maju serbski normi iednostavno, nie znam. Sluhaiu serbsku muziku narodniakokh, liebo vikhodza tam dze serbski narodniaki, liebo taki fori, nie znam, teraz tochno, znash tak zhe, a ked ia napriklad u Keresture ia bi nie vishol na take" (male, born in Ruski Kerestur, 1991).

${ }^{16}$ Transliteration of the original quote: "Toti Serbi tso som z nïma bula u shtrednieĭ buli dosts hlasni, spram profesorokh nie bash mali pochitovania, buli vel'o shliebodnieǐshi u odnosheniu na nasho ruske odzelienie [...], vshelïiak zhe mi u ruskim odzelieniu buli mirniěshi i strimanshi, nie bula galama na hodzinokh, alie vec zoz nas bulo chezhko vitsahnuts i toto tso zname. Bali zme she zhe poveme datso pohrishno, ta zme vets anï nie hutoreli. Po pitaniu toho, Serbi vel'o shliebodnieishi, a nam toto dakus khibi" (female, born in Ruski Kerestur, 1994). 
This construction of particular reasons why they consider themselves to be Ruthenian is based on distinctions in relation to Serbs. By defining the category "other" (Serbs) they define the category "us" (Ruthenians), which Eriksen explains as follows: "The first fact of ethnicity is the application of systematic distinctions between insiders and outsiders; between Us and Them. If no such principle exists there can be no ethnicity, since ethnicity presupposes an institutionalized relationship between delineated categories whose members consider each other to be culturally distinctive" (Eriksen, 2010, p. 23).

Referring to the above quotation from an informant, it is worth noting a broader context in which other ethnicities evolved alongside Ruthenians or had already developed prior to their migration to the region. The discourse on which the Serbian nation was established had been inspired by German Romanticism, whith an essentialist approach to ethnicity at its core (Gavrilović, 2008, p. 35). In the Ruthenian community essentialism was supported by the idea of anticipated extinction - Ruthenians often say: "If we don't stick together, we will vanish". This implies that their culture should remain unchanged, as traditional as possible, and that individuals should ideally marry within the community in order to continue the Ruthenian lineage.

Instead of thinking about identity in an essentialist manner, what I propose here is to try to approach it in terms of identification, which the cultural theorist Stuart Hall describes as a phenomenon "constructed on the back of a recognition of some common origin or shared characteristics with another person or group, or with an ideal, and with the natural closure of solidarity and allegiance established on this foundation" (Hall, 1996, p. 2).

One of my interviewees stated:

Based on my contact with other national minorities, I will only say that I've noticed that they take care of their own, their language, culture, way more than we do (male, born in Novi Sad, 1994)."

What he implied is that Ruthenians do not take care of their own culture to the same extent as some other ethnicities, and therefore they lack solidarity in how they communicate with others.

The discursive approach, on the other hand, "sees identification as a construct, a process never completed - always 'in process'. It is not determined in the sense that it can always

\footnotetext{
${ }^{17}$ Transliteration of the original quote: “Liem povem zhe som obachel u kontaktu zoz spomnutima men'shinskima narodami zhe vel'o, vel'o, vel'o barzheĭ chuvaiu svoǐo, iazik, kulturu, iak mi“" (male, born in Novi Sad, 1994).
} 
be 'won' or 'lost', sustained or abandoned" (Hall, 1996, 2). This means that people are not just born into their ethnic identities, or any kind of identity, but they are also taught how to "be", for example a Ruthenian, and can re-imagine and re-frame it in their own way. There is always a certain degree of agency involved whereby people can decide to use or talk about a certain identity, or decide not to disclose it at all - especially if it is not something obvious or visible. One of my interviewees commented on his choice not to disclose his ethnic identity as follows:

It has happened to me a couple of times that I accidentally found myself in the company of people who would talk against national minorities; I withdrew from the situation and from those people forever, without a conflict (male, born in Novi Sad, 1994). ${ }^{18}$

Agency over one's identity would mean the power to assert one's own idea and understanding, and to re-shape or model it the way they believe best fits them personally. Of course, this is only possible to a certain degree, because ethnic identities are not individual or personalized identities - they come from structures and positions of political power that are unobtainable for most people. The political power that I refer to here is the power over the production of knowledge which asserts itself as the truth (Adams, 2017). The power to create certain images, ideas or discourses often amounts to the instrumentalization of political power for personal gain or for the gain of the community. The agency that I think is at play here is how one is able to express themselves through speaking about their experiences, good or bad, taking into account that this expression is constructed within, not outside, discourse. Stuart Hall states that "precisely because identities are constructed within, not outside, discourse, we need to understand them as produced in specific historical and institutional sites within specific discursive formations and practices, by specific enunciative strategies" (Hall, 1996, p. 4). This does not mean that a person cannot have the liberty to conceive their own identity subjectively; it just means that we usually cannot step out of the existing boundaries of our own culture.

Rachel Adams writes that discourse as a term is used in a Foucauldian sense

to denote a historically contingent social system that produces knowledge and meaning. [...] Discourses are produced by effects of power within a social order, and this

\footnotetext{
${ }^{18}$ Transliteration of the original quote: "Sluchovalo she zhe som she dazkel'o raz niespodzivano nashol u takim druzhtve dze she beshedovalo protsiv natsionalnikh men'shinokh ta som she liem suptilno skloniel i zavshe she skloniel od takikh liudzokh bez konfliktu" (male, born in Novi Sad, 1994).
} 
power prescribes particular rules and categories which define the criteria for legitimating knowledge and truth within the discursive order. These rules and categories are considered a priori; that is, coming before the discourse. (...) It is as such that a discourse can mask itself as a-historical, universal, and scientific - that is, objective and stable (Adams, 2017).

Based on the narratives of my interviewees, it is evident that the factor of growing up in an urban environment and being more in contact with Serbs might have influenced the idea of belonging to both and neither of the ethnic identities, which can be understood as part of a discourse of non-ethnic identification. It can be viewed as a strategy, but in this case it seems to be based on personal experiences and a more general idea of a person's ethnicity. This is an idea that one's ethnicity should not affect their life negatively, and therefore if it is unimportant it does not need to be disclosed. As Stuart Hall writes, "identities are never unified and, in late modern times, increasingly fragmented and fractured; never singular but multiply constructed across different, often intersecting and antagonistic, discourses, practices and positions" (Hall, 1996, p. 4). One of my interviewees commented on her idea of her ethnic identity as follows:

I'm not sure how to explain it, like; I don't really mind who belongs to which nationality, and I think of myself as a Ruthenian, that's my nationality, but I don't identify as a Ruthenian because it's not my main characteristic; I love it, but it isn't my main characteristic (female, born in Novi Sad 1996). ${ }^{19}$

The first point Eriksen makes in the conclusion of his article "Linguistic Hegemony and Minority Resistance" is that "aspects of personal identity expressed through language can be extremely important for the well-being of individuals. Linguistic rights should be seen as elementary human rights" (Eriksen, 1992, p. 329). From the information presented here it is evident how this notion has been accounted for in the Serbian context, especially as a result of the cultural and historical heritage of the state as multicultural, multinational, multilingual, multi-ethnic and multi-confessional. The right to publish in minority languages, as well as to establish churches and other organizations, is guaranteed in the Constitution of the Republic of Serbia.

\footnotetext{
${ }^{19}$ Transliteration of the original quote: "Nie znam iak da tsi to obiashnïm, iagod, mnie teraz nie bitne zhe khtorei dakhto natsionalnostsi, $i$ ia teraz heĭ dumam za sebe zhe som Ruskinia, $i$ to moja natsionalnosts, alie she ia nie identifikuiem zhe e ia Ruskinia, iakoshik to mi, nie moia hlavna osobina, ia hel to liubim, alie to nie moia hlavna osobina" (female, born in Novi Sad, 1996).
} 
The lingua franca in Serbia is Serbian, and it is expected of all ethnicities to be taught the Serbian language and literature as a prerequisite in the curriculum in all schools. The key point here, however, is that there have been no attempts at the linguistic assimilation of the Ruthenian minority in Serbia so far. The strategic position taken by Ruthenians, in turn, has in fact been to comply with the expected bilingualism. They have not perceived it as discrimination, and nor has it affected their ethnic identity to a point of assimilation or eradication. Although assimilation might occur spontaneously, there has never been a specific political agenda of this kind. One of my interviewees talked about her bilingualism as follows:

I went to nursery school long before I began speaking, so I listened to Ruthenian and Serbian at the same time: Ruthenian at home and Serbian at nursery school. The moment I started speaking Ruthenian, I also spoke Serbian (female, born in Novi Sad, 1994). ${ }^{20}$

The informants from Novi Sad have had a similar experience: when they began speaking as children, they were able to speak both Serbian and Ruthenian. None of them stated that this was something negative or something that they would change. It is evident, then, that this practice of non-confrontational approach to the expectations of the nation-state is something that has been a strategy, and that it involved mutual respect as well as nondiscriminatory conduct, at least in political and structural terms. When it comes to individuals in general, although they may not have always been as fortunate, most of the community in Novi Sad has not experienced problems as far as I know.

This kind of opennes and willingness to comply with certain rules rather than go against them - as well as the support and understanding on the part of the nation-state - have definitely been an asset in obtaining minority rights, an outcome favourable to both parties.

\section{Conclusion}

The information presented in this article provides evidence that since their migration to present-day AP Vojvodina, Serbia, Pannonian Ruthenians have had a chance to protect their language, heritage and cultural identity, as well as to develop politically. I believe that one of the greatest tools of gaining power over one's own narrative is language, or, to be

\footnotetext{
${ }^{20}$ Transliteration of the original quote: "Do ovodi som pochala khodzits vel'o skorei iak tso som pochala beshedovats, ta som istochashnie slukhala i ruski i serbski iazik, ruski doma, a serbski u ovodi. U khvil'ki ked som prehvarela po ruski, prehvarela som i po serbski" (female, born in Novi Sad, 1994).
} 
more precise, the means of literacy and education. The codification and standardization of one of the youngest Slavic literary languages was crucial for the use of knowledge and for power over their own identity. Once they were recognized as a distinct ethnicity, they were able to obtain minority rights; consequently their language became one of the six official languages in AP Vojvodina, Serbia.

The identity narratives studied here illustrate the complexities of understanding one's own ethnic identity as well as minority experience. They also show the many contradictions and uncertainties underlying one's beliefs when it comes to identifying where and why one belongs in this modern multicultural and multilingual world.

It is important to point out that having migrated to the region Ruthenians found themselves in a multicultural environment, which made it possible for them to maintain their language, religious beliefs, culture and heritage. However, their minority rights would not have been possible without the willingness and openness on the part of the nationstates they lived in. The key factors at play here might have been the size of the community - which has never been perceived as a threat - and the fact that Ruthenians do not oppose bilingualism. I believe that a specific combination of assertiveness and willingness to negotiate one's identity rights is what has enabled Ruthenians not only to preserve their cultural identity, but also to thrive and progress consistently. They can be considered an example for other identity minorities or ethnicities currently struggling for their rights (of course, we should never forget the specific circumstances and the context in which Ruthenians were able to do so).

I will conclude this study with one of my favourite quotes from a science fiction author and a philosopher in her own right, Ursula K. Le Guin, cited by Maria Popova: "Words are events, they do things, change things. They transform both speaker and hearer; they feed energy back and forth and amplify it. They feed understanding or emotion back and forth and amplify it" (Popova, 2015).

\section{Bibliography}

Adams, R. (2017, November 17). Michel Foucault:Discourse. Retrieved April 8, 2019, from http:// criticallegalthinking.com/2017/11/17/michel-foucault-discourse/

Barthes, R. (1975). An introduction to the structural analysis of narrative (L. Duisit, Trans.). New Literary History, 6(2), 237-272. https://doi.org/10.2307/468419 
The Constitution of the Republic of Serbia. (2006). Retrieved November 7, 2019, from http://www .parlament.gov.rs/upload/documents/Constitution_\%20of_Serbia_F.pdf

Eriksen, T.H. (1992). Linguistic hegemony and minority resistance. Journal of Peace Research, 29(3), 313-332. https://doi.org/10.1177/0022343392029003007

Eriksen, T. H. (1993). Ethnicity and nationalism: Anthropological perspectives. London: Pluto Press. Eriksen, T. H. (2010). Anthropological perspectives (3rd ed.). London: Pluto Press.

Gavrilović, L. (2008). Muzeji i geografije (nacionalne) moći. In L. Gavrilović \& M. Stojanović (Eds.), Muzeji u Srbiji: Započeto putovanje (pp. 33-45). Beograd: Muzejsko društvo Srbije.

Grillo, R. D. (2003). Cultural essentialism and cultural anxiety. Anthropological Theory, 3(2), 157-173. https://doi.org/10.1177/1463499603003002002

Hall, S. (1996). Introduction: Who needs identity? In S. Hall \& P. du Gay (Eds.), Questions of cultural identity (pp. 1-17). London: Sage. https://doi.org/10.4135/9781446221907.n1

Jackson, M. (2002). The politics of storytelling. Copenhagen: Museum Tusculanum Press.

Labosh, F. (1979). Istoriia Rusinokh Bachkel, Srimu i Slavoniï 1745-1918: Doselienie gazdovski, prosvitni, kulturni i dukhovni zhivot. Vukovar: Soiuz Rusinokh i Ukraïntsokh Horvatskel.

Litwin, H. (1987). Catholicization among the Ruthenian nobility and assimilation processes in the Ukraine during the years 1569-1648. Acta Poloniae Historica, 55, 57-83.

Magosci, P. R. (1995). The Rusyn Question. Political Thought, 1995(2-3(6)), 221-231. Retrieved April 8, 2019, from http://www.litopys.org.ua/rizne/magocie.htm

Popova, M. (2015, October 21). Telling is listening: Ursula K. Le Guin on the magic of real human conversation. Retrieved April 8, 2019, from https://www.brainpickings.org/2015/10/21/telling -is-listening-ursula-k-le-guin-communication/

Ramač, J. (1996). Chuvanie natsionalnoho identiteta Rusnatsokh u luzhne ̈ Uhorskel̆. In lu. Tamash \& S. Sabo (Eds.), Rusnatsi/Rusini 1745-1995 (pp. 307-330). Novi Sad: Zavod za udžbenike i nastavna sredstva.

Savez Rusina Ukrajinaca Srbije. (n.d.). Retrieved 11 November 2019, from http://www.rusuk. org/ruski/organizacija/index.htm

Simić, M. (2006). Exit u Evropu: Popularna muzika i politike identiteta u savremenoj Srbiji. Kultura, 2006(116-117), 98-122. Retrieved April 8, 2019, from http://www.casopiskultura.rs /MagazinePublication/Details?magazinePublicationld=1831

Statistical Office of the Republic of Serbia, Census 2011, Comparative overview of the number of population in 1948, 1953, 1961, 1971, 1981, 1991, 2002, 2011. (n.d.). Retrieved November 7, 2019, from https://www.stat.gov.rs/en-US/oblasti/popis/popis-2011/popisni-podaci-eksel-tabele

Tamaš, J. (1984). Rusinska književnost. Novi Sad: Izdavačka radna organizacija Matice srpske.

Tamaš, J. (1997). Istorija ruskej literaturi. Beograd: Zavod za udžbenike i nastavna sredstva.

Tamaš, J. (2008). Poezija na ruskim literaturnim jaziku. Novi Sad: Ruske Slovo.

Véghseő, T. (2015). Reflections on the Background to the Union of Uzhhorod / Ungvár (1646). Eastern Theological Journal, 1(1): 147-181. 
Young, J. O. (2005). Profound offense and cultural appropriation. The Journal of Aesthetics and Art Criticism, 63(2), 135-146. https://doi.org/10.1111/j.0021-8529.2005.00190.x

Zlodi, Z. (2011). Rusini o sebi na stranicama Ruskih novina (Ruski Novini). Časopis za suvremenu povijest, 43(1), 183-223.

\title{
Narracje tożsamości etnicznej i języka wśród młodych Rusinów Panońskich w Serbii
}

\begin{abstract}
Niniejszy artykuł poświęcony jest narracjom tożsamości etnicznej wśród młodych Rusinów w Serbii. Analizowane dane pochodzą z wywiadów pogłębionych i badań kwestionariuszowych przeprowadzonych w roku 2016 wśród dziewięciorga rozmówców studiujących na Uniwersytecie w Nowym Sadzie. Podejście narracyjne zostało wybrane jako najwygodniejsze do zbadania osobistych spojrzeń na własną tożsamość etniczną i językową. Aby pomóc w zrozumieniu położenia Rusinów jako mniejszości etnicznej w Serbii, praca przedstawia również w zwięzły sposób kontekst historyczny, w tym informacje o migracji Rusinów z Zakarpacia do Wojwodiny w XVIII wieku, strategie ich funkcjonowania w państwach narodowych, na obszarze których zamieszkiwali, grekokatolicką identyfikację religijną, stanowiącą czynnik odróżniający ich od innych miejscowych społeczności, oraz indywidualne sposoby rozumienia tożsamości etnicznej. Położona w północnej Serbii Wojwodina to region wielokulturowy i wielowyznaniowy, co przynosi rusińskiej wspólnocie zarówno trudności, jak i korzyści. Zawarte w artykule spojrzenie na historię ukazuje ponadto proces zdobywania praw mniejszości przez Rusinów po ich migracji do obecnego miejsca zamieszkania.
\end{abstract}

\section{Słowa kluczowe:}

etniczność; mniejszość etniczna; mniejszość językowa; Rusini; standaryzacja języka; narracja; mniejszości słowiańskie

\section{Narratives of ethnic identity and language among young Pannonian Ruthenians in Serbia}

This article offers a study of narratives of ethnic identity among young Ruthenians in Serbia. The analysed data comes from in-depth interviews and questionnaires conducted in 2016 with nine informants studying at the University of Novi Sad. The narrative approach has proven to be most suitable, especially when trying to understand the individual perspective of one's ethnic and linguistic identity. In order to understand Ruthenians as an ethnic minority in Serbia, the study also provides a brief overview of the historical context, including information on Ruthenian migration from Transcarpathia to Vojvodina in the eighteenth century, their strategic positioning towards the nation states they have lived in, their GreekCatholic denomination as a factor distinguishing them from other ethnic communities, as well as the intersubjective understanding of their ethnic identity. Vojvodina, the northern 
region of Serbia, where they live, is a multicultural and multi-confessional province, which has proven to be both an opportunity and a challenge for this community. The historical overview also presents how they have obtained their minority rights since their migration to the region.

\section{Keywords:}

ethnicity; ethnic minority; linguistic minority; Ruthenians/Rusyns (Rusini); language standardization; narrative; Slavic minority

\section{Citation:}

Sakač, M. (2019). Narratives of ethnic identity and language among young Pannonian Ruthenians in Serbia. Adeptus, 2019(14). https://doi.org/10.11649/a.1983 